\title{
IDENTIFIKASI FAKTOR INTERNAL YANG MENYEBABKAN PEMBENGKAKAN BIAYA PERALATAN PADA PROYEK KONSTRUKSI GEDUNG BERTINGKAT
}

\author{
Rudy Andika ${ }^{1}$ dan Jane Sekarsari $\mathbf{T}^{2}$ \\ ${ }^{\text {I}}$ Program Studi Sarjana Teknik Sipil, Universitas Tarumanagara, Jl. Letjen S. Parman No. 1 Jakarta \\ Email: rudyandika9@gmail.com \\ ${ }^{2}$ Program Studi Sarjana Teknik Sipil, Universitas Tarumanagara, Jl. Letjen S. Parman No. 1 Jakarta \\ Email:tamtana.js@gmail.com
}

\begin{abstract}
ABSTRAK
Salah satu permasalahan yang timbul pada pelaksanaan konstruksi gedung bertingkat adalah terjadinya pembengkakan biaya. Biaya peralatan merupakan komponen biaya yang sering luput dari pengendalian, sehingga ada kecenderungan meningkat akibat lemahnya pengendalian. Usaha awal yang dapat dilakukan untuk meminimalisasi terjadinya pembengkakan biaya peralatan adalah dengan mengidentifikasi faktor-faktor internal penyebab terjadinya pembengkakan biaya peralatan. Faktor internal pembengkakan biaya peralatan dibagi kedalam 6 kelompok faktor, yaitu kelompok perencanaan dan pengendalian, kelompok pengorganisasian, kelompok pengadaan, kelompok operasional, kelompok pemeliharaan, dan kelompok pengawasan dan pengendalian. Studi ini dilakukan dengan menyebarkan kuesioner kepada para praktisi lapangan proyek konstruksi gedung bertingkat, seperti project manager, site manager, quantity of surveyor, quality of control, engineer, dll. Sebanyak 70 kuesioner yang telah disebarkan, jumlah kuesioner yang terkumpul kembali sebanyak 51 kuesioner. Analisis data menggunakan metode statistik deskriptif, hasil yang didapat bahwa faktor pengorganisasian merupakan sumber utama pada pembengkakan biaya peralatan pada proyek konstruksi gedung bertingkat.
\end{abstract}

Kata kunci: faktor internal, biaya peralatan, pembengkakan biaya peralatan, proyek konstruksi

\section{PENDAHULUAN}

\section{Latar Belakang}

Proyek konstruksi merupakan kegiatan yang dibatasi oleh waktu dan sumber daya seperti biaya, material, peralatan, dan manusia sehingga membutuhkan manajemen proyek mulai dari fase konseptual hingga fase implementasi. Semakin tinggi tingkat kompleksitas proyek dan semakin langkanya sumber daya maka akan dibutuhkan juga sistem pengelolaan dan pengendalian proyek yang lebih baik dan terintegrasi.

Tipe proyek bangunan komersial (kompleks perumahan, apartemen, bangunan perkantoran, pusat perbelanjaan, kompleks ruko, perhotelan) maupun bangunan fasilias umum (gedung sekolah, gedung pemerintahan, sarana rekreasi, pasar dan terminal) lebih sering mengalami pembengkakan biaya, dibandingkan dengan bangunan industri (Santoso, 1999). Agar nilai overrun bisa diperkecil pada proyek berikutnya, maka perlu mengetahui penyebab dominan terjadinya pembengkakan biaya dari segi perencanaan dan pelaksanaan, koordinasi sumber daya, pengendalian keuangan dan waktu.

Menurut Pandey (2012), salah satu penyebab keterlambatan dan pembengkakan biaya adalah masalah peralatan. Biaya peralatan merupakan biaya yang dikeluarkan untuk pengadaan dan operasional peralatan berat dan ringan. Biaya ini terdiri dari biaya kepemilikan alat, biaya sewa alat, dan biaya operasional alat. Kontribusi biaya peralatan terhadap total biaya proyek konstruksi gedung bertingkat adalah sekitar 10 - 15\% (Kerzner, 2009).

Dengan melihat besarnya presentase biaya peralatan terhadap biaya total proyek, maka studi ini ingin meneliti faktorfaktor internal apa saja yang dapat menyebabkan pembengkakan biaya peralatan pada proyek konstruksi gedung bertingkat. Hal ini dapat berguna untuk mencegah atau mengurangi pembengkakan biaya yang diakibatkan masalah peralatan pada proyek konstruksi gedung bertingkat. 


\section{TINJAUAN PUSTAKA}

\section{Konsep Biaya Proyek}

Untuk memahami pengelohaan peralatan, dimulai dengan mendefinisikan konsep biaya proyek, sehingga dapat diidentifikasikan komponen biaya peralatan yang akan dikelola. Dalam pembangunan suatu proyek konstruksi diperlukan sejumlah biaya yang dikelompokkan menjadi dua kelompok besar yaitu (Asiyanto, 2010) :

1. Biaya Langsung (direct cost)

2. Biaya Tidak Langsung (indirect cost)

Biaya langsung (direct cost) adalah seluruh biaya yang berkaitan langsung dengan fisik proyek, meliputi seluruh biaya dari kegiatan yang dilakukan proyek (dari persiapan hingga penyelesaian). Komponen utama dari biaya langsung ini adalah material, tenaga kerja, sub kontraktor dan alat. Biaya langsung ini juga biasa disebut dengan biaya tidak tetap (variable cost), karena jumlah biaya yang terjadi untuk setiap satuan waktu tidak tetap, tetapi tergantung kegiatan proyek yang bersangkutan. Ditinjau dari hasil kegiatan, maka yang termasuk kelompok biaya langsung adalah biayabiaya untuk pekerjaan persiapan, pekerjaan struktur bawah, pekerjaan struktur atas, pekerjaan finishing, pekerjaan mekanikal dan elektrikal, yang di dalam item-item perkerjaan tersebut pada dasarnya terkandung biaya upah, biaya bahan, dan biaya alat (Asiyanto, 2010).

Biaya tidak langsung (indirect cost) dalam proyek adalah biaya yang harus dikeluarkan untuk kegiatan yang tidak berkaitan secara langsung dengan proyek yang bersangkutan, yang hasilnya tidak berbentuk fisik, melainkan bersifat mendukung pekerjaan konstruksi. Oleh karena itu, besar kecilnya biaya ini kurang atau tidak dipengaruhi oleh kegiatan proyek. Biaya indirect cost bukanlah komponen biaya konstruksi yang aktual tetapi dapat menimbulkan problem bagi kontraktor dalam mendukung pekerjaan proyek, biaya ini biasanya dikategorikan sebagai biaya overhead (Asiyanto, 2010).

\section{Manajemen Biaya Proyek}

Manajemen biaya proyek termasuk dari proses yang diperlukan untuk memastikan bahwa proyek telah lengkap dan sesuai dengan biaya yang disetujui. Menurut Nicholas (2008), manajemen biaya proyek ini meliputi : Resource Planning, Cost Estimating, Cost Budgeting, dan Cost Controling. Resource Planning ialah penentuan dari sumber daya fisik (orang, peralatan, material) dan berapa jumlah dari masing- masing harus digunakan dan kapan sumber daya fisik itu akan dibutuhkan untuk menyelenggarakan aktifitas proyek.

Estimasi biaya proyek adalah perkiraan tentang kemungkinan biaya yang akan digunakan pada proyek konstruksi. Pembuatan estimasi biaya ini memerlukan pengetahuan mengenai semua tahapan proyek konstruksi. Kesesuaian antara estimasi biaya dengan biaya sesungguhnya akan sangat bergantung pada keterampilan, penilaian, dan pengalaman dari estimator (Nugroho, 2012).

Menurut Asiyanto (2010), kegunaan dari cost budget adalah untuk mematok biaya pelaksanaan, atau memberikan batasan uang yang tersedia untuk keperluan bahan, upah, alat, subkontraktor, dan lain-lain dalam total biaya proyek.

Tugas dari pada cost controlling bukan hanya mengawasi arus biaya dan menyimpan sejumlah besar data, tetapi juga melakukan suatu analisa data untuk mengambil tindakan koreksi sebelum terlambat.

\section{Manajemen Biaya Peralatan}

Secara umum, faktor-faktor penting yang merupakan permasalahan pokok dalam manajemen peralatan konstruksi mencakup: pemilihan alat, kepemilikan alat, pengoperasian / penggunaan alat, rencana pemeliharaan dan perbaikan alat serta penggantian komponen peralatan (Yudiansyah, 2002). Sebab-sebab penyimpangan biaya peralatan terhadap budget-nya, untuk masing-masing unsur biaya dapat dirinci, baik dari faktor kuantitas, maupun dari faktor harga satuan, antara lain sebagai berikut (Pandey, 2012).

Penyimpangan biaya peralatan ditinjau dari faktor kuantitas dapat disebabkan oleh hal-hal dibawah ini :

1. Kelemahan pengelolaan bahan bakar dan pelumas

2. Kelemahan pengadaan dan pengelolaan suku cadang

3. Kelebihan menghitung hour meter (jam kerja alat) untuk alat yang disewa berdasarkan jam kerja alat

4. Kesalahan memilih metode pelaksanaan yang menyebabkan kelebihan atas kebutuhan alat

5. Kelemahan pengaturan alat dilapangan, sehingga menimbulkan idle cost 
Penyimpangan biaya alat ditinjau dari faktor harga satuan dapat disebabkan oleh hal-hal dibawah ini :

1. Kelemahan dalam negosiasi dengan pemilik alat yang disewa, dan supplier suku cadang

2. Kelemahan dalam pasal-pasal dalam surat perjanjian sewa alat dan pembelian suku cadang

3. Kesalahan dalam memilih jenis alat

4. Kesalahan dalam menetapkan kombinasi dan jumlah komposisi alat yang bekerja dalam kelompok (group)

5. Kesalahan atau kelemahan dalam pengaturan alat dilapangan

6. Kondisi alat yang produktivitasnya rendah

\section{Pembengkakan Biaya Peralatan}

Menurut Pandey (2012), faktor-faktor pembengkakan biaya peralatan dikelompokkan dalam 2 kelompok besar, yaitu kelompok internal dan kelompok eksternal.

1. Kelompok Internal
a. Perencanaan dan Penjadwalan
d. Operasional
b. Pengorganisasian
e. Pemeliharaan
c. Pengadaan
f. Pengawasan dan Pengendalian

2. Kelompok Eksternal
a. Lingkungan
b. Politik
c. Ekonomi
d. Legal/Hukum

\section{METODOLOGI PENELITIAN}

\section{Populasi dan Sampel Penelitian}

Populasi dalam penelitian ini adalah parapara praktisi lapangan dari perusahaan konstruksi yang ada di DKI Jakarta. Sampel pada penelitian ini diambil lebih dari 40 responden. Metode pengambilan sampel menggunakan metode non probability sampling. Teknik sampling yang digunakan adalah purposive sampling yaitu pengambilan sampel yang membatasi pada ciri-ciri khusus seseorang. Kriteria dalam pengambilan sampel penelitian adalah project manger, site manajer, quality of control, quantity of surveyor, engineer, dan pihak-pihak yang dapat mengambil keputusan dalam proyek konstruksi.

\section{Teknik Pengumpulan Data}

Pengumpulan data menggunakan kuesioner yang telah disusun dan pengukuran menggunakan skala Likert seperti pada tabel 1 .

Tabel 1. Skala Likert Penelitian

\begin{tabular}{cc}
\hline Skala & Penilaian \\
\hline 5 & Sangat Mempengaruhi \\
\hline 4 & Mempengaruhi \\
\hline 3 & Cukup Mempengaruhi \\
\hline 2 & Kurang Mempengaruhi \\
\hline 1 & Tidak Mempengaruhi \\
\hline
\end{tabular}

\section{Diagram Alir Penelitian}

Studi ini ingin melakukan identifikasi faktor-faktor internal yang menyebabkan pembengkakan biaya pada proyek konstruksi gedung bertingkat, diagram alir penelitian ini dapat dilihat pada gambar 1 . 


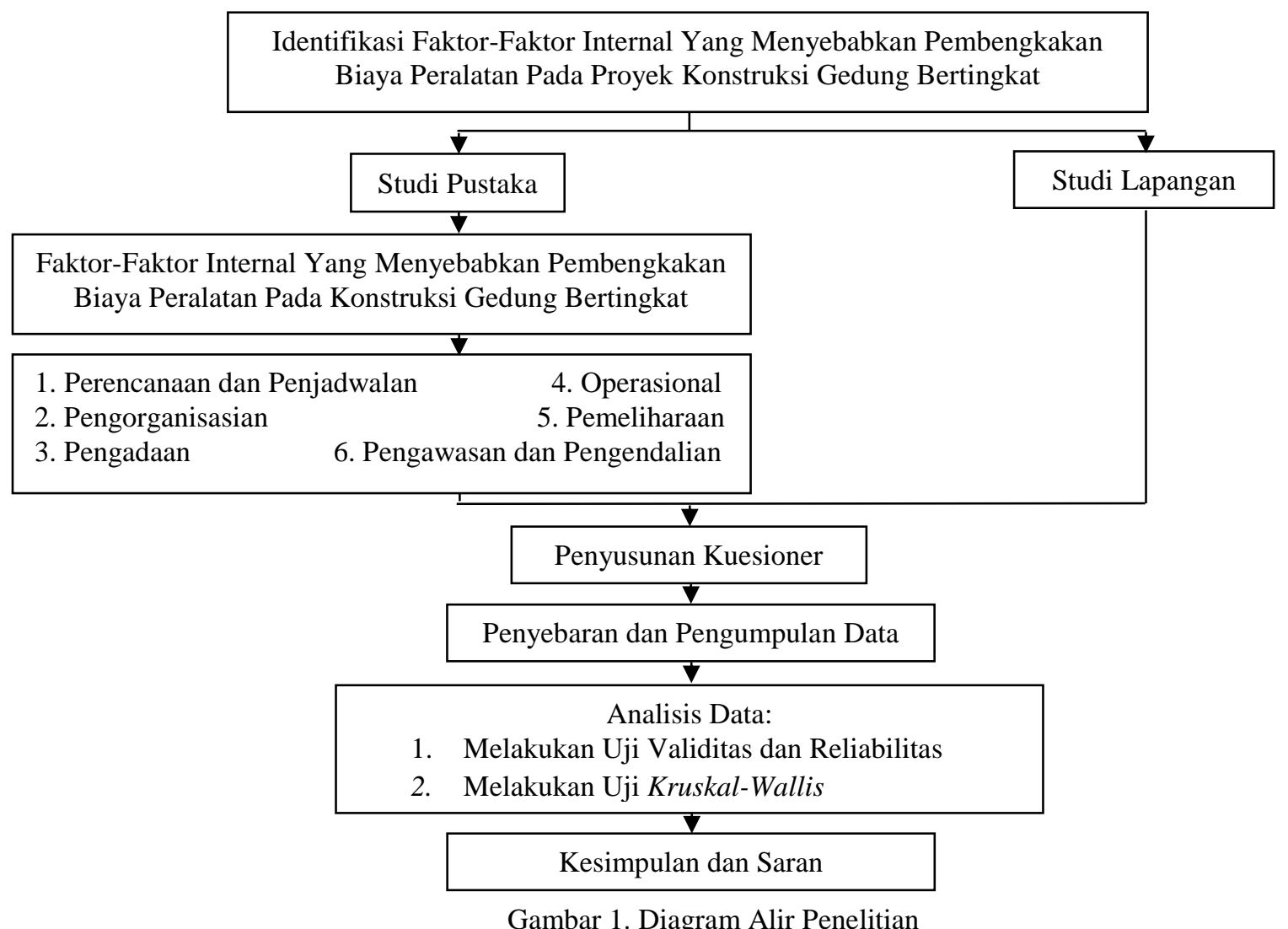

\section{Variabel Penelitian}

Dari hasil tinjauan pustaka dari beberapa literatur yang dilakukan pada bab sebelumnya, maka didapatkan variabel yang digunakan dalam penelitian adalah sebagai berikut.

Tabel 2. Variabel-Variabel Pembengkakan Biaya Peralatan

\begin{tabular}{|c|c|}
\hline No. & Penyebab Pembengkakan Biaya Peralatan Proyek Konstruksi \\
\hline \multicolumn{2}{|r|}{ A. Perencanaan dan Penjadwalan } \\
\hline A.1 & Kesalahan dalam merencanakan perkiraan, sehingga pelaksanaan tidak sesuai dengan rencana \\
\hline A. 2 & Kesalahan dalam memprediksi kondisi lapangan, cuaca dan kejadian yang akan datang \\
\hline A.3 & Kesalahan dalam merencanakan lingkup pekerjaan dan penyususan WBS \\
\hline A.4 & Data dan informasi mengenai kegiatan dan material yang kurang lengkap \\
\hline A.5 & Tidak memperhitungkan pengaruh inflasi dan eskalasi \\
\hline A.6 & Kurangnya brosur peralatan (equipment list) termasuk spesfikasi dan kuantitas \\
\hline \multicolumn{2}{|r|}{ B. Pengorganisasian } \\
\hline B.1 & Kurang baiknya koordinasi antar fungsi pada WBS \\
\hline B. 2 & Kurangnya koordinasi antara kontraktor utama dan sub kontraktor \\
\hline B.3 & Adanya perubahan pekerjaan (rework) \\
\hline B.4 & Terlambat proses pengambilan keputusan yang berdampak pada terjadi pekerjaan ulang \\
\hline \multicolumn{2}{|r|}{ C. Pengadaan } \\
\hline C.1 & Biaya mobilisasi / demobilisasi peralatan yang tinggi \\
\hline C. 2 & Tingginya biaya sewa \\
\hline C.3 & Keterlambatan dalam pengadaan peralatan yang berdampak pada terjadinya penundaan konstruksi \\
\hline \multicolumn{2}{|r|}{ D. Operasional } \\
\hline D.1 & Komposisi alat tidak seimbang yang berdampak pada penyelesaian proyek terlambat \\
\hline
\end{tabular}


Tabel 2. Variabel-Variabel Pembengkakan Biaya Peralatan (Lanjutan)

\begin{tabular}{cc}
\hline No. & Penyebab Pembengkakan Biaya Peralatan Proyek Konstruksi \\
\hline D.2 & Alat bekerja terlalu berat \\
\hline D.3 & Kelemahan pengaturan alat dilapangan, sehingga menimbulkan idle cost \\
\hline D.4 & Operator kurang terlatih dalam menangani dan mengenal keterbatasan dan kemampuan alat \\
\hline \multicolumn{2}{c}{ E. Pemeliharaan } \\
\hline E.1 & Perawatan baru dilakukan jika terjadi kerusakan pada peralatan \\
\hline E.2 3 & Peralatan sudah usang yang berdampak pada kinerja alat menurun \\
\hline F.1 & F. Pengawasan dan Pengendalian \\
\hline F.2 & Kesalahan dalam mengatur penyimpanan suku cadang peralatan \\
\hline F. 3 & Tidak dilakukan pemeriksaan berkala terhadap peralatan \\
\hline
\end{tabular}

\section{Pengujian Data}

Pengujian dilakukan dengan menggunakan bantuan software SPSS. Adapun teknik analisis data yang dilakukan dalam penelitian ini meliputi uji validitas, uji reliabilitas, dan uji Kruskal-Wallis.

\section{ANALISIS DAN PEMBAHASAN}

Kuesioner yang disebar kepada responden ada sebanyak 70 kuesioner dan jumlah kuesioner yang kembali adalah sebanyak 51 kuesioner. Dari seluruh kuesioner yang terkumpul, sebanyak 49 kuesioner dapat digunakan untuk analisis data.

\section{Uji Validitas}

Uji validitas dilakukan dengan melihat nilai $\mathrm{r}$ hitung pada kolom corrected total item correlation. Apabila nilai $\mathrm{r}$ hitung $\geq \mathrm{r}$ tabel, maka butir tersebut dapat dikatakan valid. Butir yang tidak valid harus direduksi mulai dari yang memiliki nilai $r$ terkecil. Dengan jumlah responden sebanyak 49 orang $(\mathrm{N}=49)$, maka dari tabel $\mathrm{r}$ dengan $\mathrm{df}=\mathrm{N}-2=49-2=47$ dan taraf signifikansi 5\% akan didapatkan nilai $\mathrm{r}$ tabel sebesar 0,288. Hasil uji validitas menunjukkan bahwa variabel A.1, dan variabel B.3 tidak valid sehingga harus direduksi. Hasil setelah kedua variabel tersebut direduksi dapat dilihat pada tabel 3 .

Tabel 3. Hasil Uji Validitas

\begin{tabular}{ccccc}
\hline Variabel & $\begin{array}{c}\text { Scale Mean if } \\
\text { Item Deleted }\end{array}$ & $\begin{array}{c}\text { Scale Variance } \\
\text { if Item Deleted }\end{array}$ & $\begin{array}{c}\text { Corrected Item- } \\
\text { Total } \\
\text { Correlation }\end{array}$ & $\begin{array}{c}\text { Cronbach's } \\
\text { Alpha if Item } \\
\text { Deleted }\end{array}$ \\
\hline A.2 & 77.4898 & 121.463 & .412 & .908 \\
\hline A.3 & 77.4694 & 123.546 & .342 & .909 \\
\hline A.4 & 77.3878 & 121.826 & .354 & .909 \\
\hline A.5 & 77.7959 & 120.666 & .391 & .908 \\
\hline A.6 & 78.1429 & 119.333 & .422 & .908 \\
\hline B.1 & 77.5306 & 120.338 & .514 & .906 \\
\hline B.2 & 77.2449 & 119.439 & .546 & .905 \\
\hline B.4 & 77.3878 & 117.951 & .548 & .905 \\
\hline C.1 & 77.7755 & 122.344 & .341 & .909 \\
\hline C. 2 & 77.6122 & 119.701 & .493 & .906 \\
\hline C.3 & 77.4286 & 117.708 & .591 & .904 \\
\hline D.1 & 77.7347 & 115.907 & .591 & .908 \\
\hline D. 2 & 78.3265 & 118.724 & .432 & .904 \\
\hline D.3 & 77.8367 & 116.514 & .554 & \\
\hline
\end{tabular}


Tabel 3. Hasil Uji Validitas (Lanjutan)

\begin{tabular}{ccccc}
\hline Variabel & $\begin{array}{c}\text { Scale Mean if } \\
\text { Item Deleted }\end{array}$ & $\begin{array}{c}\text { Scale Variance } \\
\text { if Item Deleted }\end{array}$ & $\begin{array}{c}\text { Corrected Item- } \\
\text { Total } \\
\text { Correlation }\end{array}$ & $\begin{array}{c}\text { Cronbach's } \\
\text { Alpha if Item } \\
\text { Deleted }\end{array}$ \\
\hline D.4 & 77.8571 & 113.292 & .710 & .900 \\
\hline E.1 & 77.7347 & 114.907 & .642 & .902 \\
\hline E.2 & 77.7755 & 112.678 & .694 & .901 \\
\hline E.3 & 77.6939 & 116.675 & .613 & .903 \\
\hline F.1 & 78.102 & 113.135 & .696 & .901 \\
\hline F.2 & 77.7959 & 113.416 & .755 & .899 \\
\hline F.3 & 77.7143 & 115.083 & .655 & .902 \\
\hline
\end{tabular}

Setelah mereduksi variabel A.1 dan B.3, dapat dilihat bahwa seluruh variabel yang tersisa sudah valid karena memiliki nilai $r$ hitung yang lebih besar dari $r$ tabel $=0,288$

\section{Uji Reliabilitas}

Uji reliabilitas dilakukan dengan melihat nilai cronbach's alpha yang harus lebih besar dari 0,6. Dari hasil analisis setelah melakukan reduksi terhadap 2 buah variabel agar memenuhi syarat validitas, nilai cronbach's alpha didapat seperti pada tabel 4 .

Tabel 4. Nilai Cronbach's Alpha

\begin{tabular}{cc}
\hline Cronbach's Alpha & N of Items \\
\hline .909 & 21 \\
\hline
\end{tabular}

Dari tabel tersebut dapat disimpulkan bahwa data penelitian ini memiliki reliabilitas yang sangat tinggi.

\section{Analisis Deskriptif}

Analisis deskriptif dilakukan untuk mendapatkan nilai rata-rata (mean) dari keseluruhan variabel yang ditanyakan kepada beberapa responden. Hal ini bertujuan untuk mengetahui variabel yang paling mempengaruhi dan menentukan dari faktor-faktor internal yang menyebabkan pembengkakan biaya perlatan.

Tabel 5. Hasil Analisis Deskriptif Masing-Masing Variabel

\begin{tabular}{cccccc}
\hline Variabel & N & Minimum & Maximum & Mean & Std. Deviation \\
\hline A. 2 & 49 & 2 & 5 & 4.102 & .79700 \\
\hline A.3 & 49 & 2 & 5 & 4.1224 & .69620 \\
\hline A.4 & 49 & 2 & 5 & 4.2041 & .86553 \\
\hline A.5 & 49 & 2 & 5 & 3.7959 & .91241 \\
\hline A.6 & 49 & 1 & 5 & 3.449 & .98025 \\
\hline B.1 & 49 & 3 & 5 & 4.0612 & .74744 \\
\hline B.2 & 49 & 2 & 5 & 4.3469 & .77865 \\
\hline B.4 & 49 & 1 & 5 & 4.2041 & .88928 \\
\hline C. 1 & 49 & 2 & 5 & 3.8163 & .83350 \\
\hline C. 2 & 49 & 2 & 5 & 3.9796 & .82890 \\
\hline C. 3 & 49 & 2 & 5 & 4.1633 & .85017 \\
\hline D. 1 & 49 & 1 & 5 & 3.8571 & .97895 \\
\hline D. 2 & 49 & 1 & 5 & 3.2653 & 1.01603 \\
\hline D. 3 & 49 & 1 & 5 & 3.7551 & .99017 \\
\hline D. 4 & 49 & 2 & 5 & 3.7347 & .99531 \\
\hline E.1 & 49 & 2 & 5 & 3.8571 & .97895 \\
\hline
\end{tabular}


Tabel 5. Hasil Analisis Deskriptif Masing-Masing Variabel (Lanjutan)

\begin{tabular}{cccccc}
\hline Variabel & N & Minimum & Maximum & Mean & Std. Deviation \\
\hline E.2 & 49 & 2 & 5 & 3.8163 & 1.05423 \\
\hline E.3 & 49 & 2 & 5 & 3.898 & .89547 \\
\hline F.1 & 49 & 1 & 5 & 3.4898 & 1.02312 \\
\hline F.2 & 49 & 2 & 5 & 3.7959 & .93496 \\
\hline F.3 & 49 & 2 & 5 & 3.8776 & .94940 \\
\hline Valid N (listwise) & 49 & & & & \\
\hline
\end{tabular}

Dari tabel 5, dapat dilihat Variabel B.2 (kurangnya koordinasi antara kontraktor utama dan sub kontraktor) memiliki nilai mean yang paling besar, yaitu 4,3469, diikuti oleh Variabel A.4 (data dan informasi mengenai kegiatan dan material yang kurang lengkap yang berdampak pada banyaknya pekerjaan tambahan yang tidak sesuai kontrak) sebesar 4,2041, dan Variabel B.4 (proses pengambilan keputusan yang berdampak pada terjadi pekerjaan ulang) sebesar 4,2041 .

Tabel 6. Hasil Analisis Deskriptif Variabel

\begin{tabular}{cccccc}
\hline Variabel & N & Minimum & Maximum & Mean & Std. Deviation \\
\hline A & 49 & 1 & 5 & 3.934694 & .5543581 \\
\hline B & 49 & 1 & 5 & 4.204082 & .5766134 \\
\hline C & 49 & 2 & 5 & 3.986395 & .6699889 \\
\hline D & 49 & 1 & 5 & 3.653061 & .7736149 \\
\hline E & 49 & 2 & 5 & 3.857143 & .8633483 \\
\hline F & 49 & 1 & 5 & 3.721088 & .8315173 \\
\hline Valid N (listwise) & 49 & & & & \\
\hline
\end{tabular}

Dari tabel 6, dapat dilihat Variabel B (Pengorganisasian) memiliki nilai mean yang paling besar, yaitu 4,2041, diikuti oleh Variabel C (Pengadaan) sebesar 3,9864, dan Variabel A (Perencanaan dan Pengendalian) sebesar 3,9347.

\section{Uji Kruskal-Wallis}

1. Kelompok Usia Responden

Hipotesis :

- Ho : Tidak ada perbedaan faktor internal menurut kelompok responden yang berusia dibawah dua puluh lima tahun, berusia diantara dua puluh lima hingga tiga puluh tahun, berusia diantara tiga puluh tahun hingga tiga puluh lima tahun, dan berusia diatas tiga puluh lima tahun.

- Ha : Ada perbedaan faktor internal menurut kelompok responden yang berusia dibawah dua puluh lima tahun, berusia diantara dua puluh lima hingga tiga puluh tahun, berusia diantara tiga puluh tahun hingga tiga puluh lima tahun, dan berusia diatas tiga puluh lima tahun

Tabel 7. Hasil Uji Kruskal-Wallis Kelompok Usia

\section{Test Statistics $^{\mathrm{a}, \mathrm{b}}$}

\begin{tabular}{lccccccc}
\hline & A.2 & A.3 & A.4 & A.5 & A.6 & B.1 & B.2 \\
\hline $\begin{array}{l}\text { Chi- } \\
\text { Square }\end{array}$ & .279 & .277 & .922 & 2.141 & 4.298 & 2.846 & .371 \\
\hline df & 3 & 3 & 3 & 3 & 3 & 3 & 3 \\
\hline $\begin{array}{l}\text { Asymp. } \\
\text { Sig. }\end{array}$ & .964 & .964 & .820 & .544 & .231 & .416 & .946 \\
\hline
\end{tabular}
a. Kruskal Wallis Test
b. Grouping Variable: Usia 
Tabel 7. Hasil Uji Kruskal-Wallis Kelompok Usia (Lanjutan)

Test Statistics $^{\text {a,b }}$

\begin{tabular}{lccccccc}
\hline & B.4 & C.1 & C.2 & C.3 & D.1 & D.2 & D.3 \\
\hline $\begin{array}{l}\text { Chi- } \\
\text { Square }\end{array}$ & 6.658 & 1.963 & 2.119 & 1.153 & .446 & 2.022 & .460 \\
\hline df & 3 & 3 & 3 & 3 & 3 & 3 & 3 \\
\hline $\begin{array}{l}\text { Asymp. } \\
\text { Sig. }\end{array}$ & .084 & .580 & .548 & .764 & .931 & .568 & .927 \\
\hline
\end{tabular}
a. Kruskal Wallis Test
b. Grouping Variable: Usia

Test Statistics $^{\mathrm{a}, \mathrm{b}}$

\begin{tabular}{lccccccc}
\hline & D.4 & E.1 & E.2 & E.3 & F.1 & F.2 & F.3 \\
\hline $\begin{array}{l}\text { Chi- } \\
\text { Square }\end{array}$ & 1.578 & 2.611 & 2.198 & 2.418 & 3.270 & 6.104 & 6.018 \\
\hline df & 3 & 3 & 3 & 3 & 3 & 3 & 3 \\
\hline $\begin{array}{l}\text { Asymp. } \\
\text { Sig. }\end{array}$ & .664 & .456 & .532 & .490 & .352 & .107 & .111 \\
\hline
\end{tabular}

a. Kruskal Wallis Test

b. Grouping Variable: Usia

Berdasarkan tabel 7, hasil uji Kruskal-Wallis nilai Asymp. Sig. untuk tiap variabel lebih dari 0.05 (Asymp. Sig. > 0.05). Maka terjadi gagal tolak Ho, artinya tidak ada perbedaan menurut kelompok responden yang berusia dibawah dua puluh lima tahun $(<25$ Tahun), berusia diantara dua puluh lima hingga tiga puluh tahun $(25$ - 30 Tahun), berusia diantara tiga puluh tahun hingga tiga puluh lima tahun $(30-35$ Tahun), dan berusia diatas tiga puluh lima tahun ( $>35$ Tahun).

2. Kelompok Pengalaman Kerja Responden

Hipotesis :

- Ho : Tidak ada perbedaan menurut kelompok responden yang lama bekerjanya dibawah lima tahun $(<5$ Tahun), lama bekerjanya diantara lima hingga sepuluh tahun (5 - 10 Tahun), lama bekerjanya diantara sepuluh tahun hingga lima belas tahun $(10-15$ Tahun), dan lama bekerjanya diatas lima belas tahun $(>15$ Tahun).

- Ha : Ada perbedaan menurut kelompok responden yang lama bekerjanya dibawah lima tahun ( $<5$ Tahun), lama bekerjanya diantara lima hingga sepuluh tahun (5 - 10 Tahun), lama bekerjanya diantara sepuluh tahun hingga lima belas tahun (10 - 15 Tahun), dan lama bekerjanya diatas lima belas tahun (>15 Tahun).

Tabel 8. Hasil Uji Kruskal-Wallis Kelompok Pengalaman Kerja

Test Statistics $^{\text {a,b }}$

\begin{tabular}{lccccccc}
\hline & A.2 & A.3 & A.4 & A.5 & A.6 & B.1 & B.2 \\
\hline $\begin{array}{l}\text { Chi- } \\
\text { Square }\end{array}$ & .660 & 2.641 & 2.274 & 1.990 & .399 & 1.832 & 1.687 \\
\hline $\mathrm{df}$ & 3 & 3 & 3 & 3 & 3 & 3 & 3 \\
\hline $\begin{array}{l}\text { Asymp. } \\
\text { Sig. }\end{array}$ & .883 & .450 & .518 & .575 & .940 & .608 & .640 \\
\hline
\end{tabular}
a. Kruskal Wallis Test
b. Grouping Variable: Pengalaman 
Tabel 8. Hasil Uji Kruskal-Wallis Kelompok Pengalaman Kerja

Test Statistics $^{\mathrm{a}, \mathrm{b}}$

\begin{tabular}{lccccccc}
\hline & B.4 & C.1 & C.2 & C.3 & D.1 & D.2 & D.3 \\
\hline $\begin{array}{l}\text { Chi- } \\
\text { Square }\end{array}$ & 2.518 & 5.695 & .876 & 4.002 & 5.595 & .933 & 1.141 \\
\hline df & 3 & 3 & 3 & 3 & 3 & 3 & 3 \\
\hline $\begin{array}{l}\text { Asymp. } \\
\text { Sig. }\end{array}$ & .472 & .127 & .831 & .261 & .133 & .817 & .767 \\
\hline
\end{tabular}

a. Kruskal Wallis Test

b. Grouping Variable: Pengalaman

Test Statistics $^{\text {a,b }}$

\begin{tabular}{lccccccc}
\hline & D.4 & E.1 & E.2 & E.3 & F.1 & F.2 & F.3 \\
\hline $\begin{array}{l}\text { Chi- } \\
\text { Square }\end{array}$ & 2.933 & 1.782 & 3.678 & 1.329 & 1.831 & .389 & 5.783 \\
\hline df & 3 & 3 & 3 & 3 & 3 & 3 & 3 \\
\hline $\begin{array}{l}\text { Asymp. } \\
\text { Sig. }\end{array}$ & .402 & .619 & .298 & .722 & .608 & .942 & .123 \\
\hline
\end{tabular}

a. Kruskal Wallis Test

b. Grouping Variable: Pengalaman

Berdasarkan tabel 8, hasil uji Kruskal-Wallis nilai Asymp. Sig. untuk tiap variabel lebih dari 0.05 (Asymp. Sig. >0.05). Maka terjadi gagal tolak Ho, artinya tidak ada perbedaan menurut kelompok responden yang lama bekerjanya dibawah lima tahun ( $<5$ Tahun), lama bekerjanya diantara lima hingga sepuluh tahun ( 5 - 10 Tahun), lama bekerjanya diantara sepuluh tahun hingga lima belas tahun $(10-15$ Tahun), dan lama bekerjanya diatas lima belas tahun ( $>15$ Tahun).

\section{KESIMPULAN}

1. Kelompok penyebab pembengkakan biaya peralatan pada proyek konstruksi gedung bertingkat dengan nilai mean terbesar berasal dari kelompok Pengorganisasian dengan nilai mean sebesar 4.2041; diikuti oleh kelompok Pengadaan dengan mean sebesar 3.9864; dan kelompok Perencanaan dan Pengendalian dengan mean sebesar 3.9347 .

2. Variabel yang paling mempengaruhi pembengkakan biaya peralatan pada proyek konstruksi gedung bertingkat adalah "kurangnya koordinasi antara kontraktor utama dan sub kontraktor" dengan nilai mean sebesar 4.3469; diikuti oleh "data dan informasi mengenai kegiatan dan material yang kurang lengkap yang berdampak pada banyaknya pekerjaan tambahan yang tidak sesuai kontrak" dengan nilai mean sebesar 4.2041; dan "proses pengambilan keputusan yang berdampak pada terjadi pekerjaan ulang" dengan nilai mean sebesar 4.2041.

3. Dari hasil uji Kruskal-Wallis berdasarkan kategori usia, dan pengalaman bekerja, tidak terdapat perbedaan antar responden (Asymp. Sig. > 0,05).

\section{DAFTAR PUSTAKA}

Asiyanto. (2010). Cosntrustion Project Cost Management. Jakarta : PT. Pradnya Paramita.

Kerzner, H.R. (2009). "Project Management : A System Approach to Planning, Scheduling and Controling”. Journal of Construction Engineering and Management, Vol. 136, No. 11.

Nicholas, John., dan Herman S. (2008). "Project Management for Business, Engineering, and Technology". Journal of Management in Engineering Vol. 15, No. 3.

Nugroho, Bayu Adi. (2012). “Analisis Faktor Keterlambatan Proyek Terhadap Pembengkakan Biaya Proyek Bangunan Gedung Di Surakarta”. Universitas Sebelas Maret.

Pandey, Raymond David. (2012). "Analisis Faktor Penyebab Pembengkakan Biaya (Cost Overrun) Peralatan pada Proyek Konstruksi Dermaga di Sulawesi Utara”. Jurnal Ilmiah Media Engineering Vol. 2, No. 3, September 2012 ISSN 2087-9334. 
Identifikasi Faktor Internal Yang Menyebabkan Rudy Andika, et al.

Pembengkakan Biaya Peralatan Pada Proyek Konstruksi

Gedung Bertingkat

Santoso, Indriani. (1999). “Analisa Overruns Biaya pada Beberapa Tipe Proyek Konstruksi”. Jurusan Dimensi Teknik Sipil Vol. 1, No. 1.

Yudiansyah. (2002). "Rekomendasi Tindakan Koreksi pada Manajemen Peralatan dalam Pengendalian Biaya Proyek dengan Bantuan Expert System”. Universitas Indonesia. 